\title{
Alzheimer's disease: Development of a sensitive label-free electrochemical immunosensor for detection of amyloid beta peptide
}

\author{
Pedro Carneiro ${ }^{\mathrm{a}, \mathrm{b}}$, Joana Loureiro ${ }^{\mathrm{a}}$, Cristina Delerue-Matos ${ }^{\mathrm{b}}$, Simone Morais ${ }^{\mathrm{b}, *}$, \\ Maria do Carmo Pereira ${ }^{a}$ \\ a LEPABE, Department of Chemical Engineering, Faculty of Engineering of the University of Porto, Rua Dr. Roberto Frias, $4200-465$ Porto, Portugal \\ ${ }^{\mathrm{b}}$ REQUIMTE-LAQV, Instituto Superior de Engenharia do Porto, Instituto Politécnico do Porto, R. Dr. António Bernardino de Almeida 431, $4200-072$ Porto, \\ Portugal
}

\author{
Keywords: \\ Alzheimer's disease \\ $\beta$-Amyloid peptide \\ Electrochemical biosensor \\ Self-assembled monolayer \\ Gold nanoparticles \\ Monoclonal antibody
}

\begin{abstract}
A B S T R A C T
In this work, a highly sensitive label-free immunosensor for detection of the main biomarker of Alzheimer's disease (AD), amyloid beta 1-42 (A $\beta(1-42))$, is presented. A gold electrode was modified with a mercaptopropionic acid (MPA) self-assembled monolayer, electrodeposited gold nanoparticles (AuNPs) and a monoclonal antibody mAb DE2B4 to recognize $A \beta$; all the relevant experimental variables were optimized. Antibodies were functionalized through chemical modification (thiolation) to promote the antibody immobilization on the AuNPs surface with proper orientation which enabled the direct detection of $A \beta(1-42)$. Scanning electron microscopy, square-wave voltammetry and electrochemical impedance spectroscopy were used to characterize the construction of the biosensor. Using the proposed immunosensor, $A \beta(1-42)$ was specifically detected within the linear range of $10-1000 \mathrm{pg} \mathrm{mL}^{-1}$ with a $5.2 \mathrm{pg} \mathrm{mL}^{-1}$ and $17.4 \mathrm{pg} \mathrm{mL}^{-1}$ detection and quantification limit, respectively; recovery values for the tested spiking levels ranged from 90.3 to $93.6 \%$. The immunosensor enables rapid, accurate, precise, reproducible and highly sensitive detection $\left(14.6 \%_{\text {reduction }} \mathrm{mL} \mathrm{pg}^{-1}\right)$ of $A \beta$ with low-cost and opens the possibilities for diagnostic ex vivo applications and research-based in vivo studies.
\end{abstract}

\section{Introduction}

Alzheimer's disease $(\mathrm{AD})$ is a neurodegenerative pathology that becomes increasingly common with aging, characterized by extracellular accumulation of amyloid $\beta$ peptide $(A \beta)$, intracellular appearance of neurofibrillary tangles and neuronal loss [1,2]. This degeneration leads to changes in behavior, personality and functional capacity, which hampers the daily life of the patient. Nowadays it affects 35 million individuals worldwide and it is estimated to affect 115 million people by 2050 [3].

The current diagnostic procedures of $\mathrm{AD}$ are difficult and made in an advanced stage of the disease. In addition, there are no treatments available that prevent this condition. Therefore, there is a continuing demand for fast and simple analytical methods for the determination of many clinical and biochemical parameters [4-6].

Research gives support to the "amyloid cascade hypothesis", which advocates that an imbalance between the production and clearance or degradation of $A \beta$ in the brain is the initiating event

\footnotetext{
* Corresponding author.

E-mail address: sbm@isep.ipp.pt (S. Morais).
}

in $A D$, leading to the formation of extracellular deposits of $A \beta$ (senile plaques) [7]. The peptide with 42 amino acids, $A \beta(1-42)$, is the major component of the senile plaques found in $\mathrm{AD}$. Other pathological hallmarks of $\mathrm{AD}$ include intraneuronal inclusions of hyperphosphorylated tau protein in neurofibrillary tangles, together with downstream processes such as inflammation and oxidative stress. All of these steps contribute to the loss of synaptic integrity, effective neural network connectivity and progressive neurodegeneration $[3,5,8,9]$.

$A \beta(1-42)$ can be expressed in cerebrospinal fluid (CSF) and plasma. More specifically, CSF levels of $A \beta(1-42)$ are lower in $A D$ patients than in normal controls, reflecting amyloid pathology. Specifically, low CSF $A \beta(1-42)$ levels are detected in preclinical disease stages and predict future cognitive decline and neurodegeneration [10]. An $A \beta(1-42)$ concentration of $<500 \mathrm{pg} \mathrm{mL}^{-1}$ $(0.1 \mathrm{nM})$ is indicative that $A \beta(1-42)$ is accumulating in the brain and not circulating in the CSF [10].

Currently, most of the $A \beta(1-42)$ assays rely on immunochemical detection such as the conventional enzyme linked immunoassay (ELISA) $[10,11]$ which are methods that present high sensitivity, good specificity and less dependence on sample preparation [12]. Recently, an ELISA assay was optimized and validated present- 
ing a detection limit of $375 \mathrm{pg} / \mathrm{mL}$ [11]. In this work we present an electrochemical immunosensor which is particularly attractive in the field of diagnosis because biosensors unite the specificity and affinity of the antibody-antigen reaction with the inherent characteristics of electrochemical techniques such as high sensitivity, low cost, high efficiency and easy miniaturization [13-16]. A critical aspect in the development of an immunosensor is the antibody immobilization. The chosen method should be capable of immobilizing a high density of antibodies, maintaining the antibodies bioactivity and promoting the antibodies immobilization with proper orientation to interact favorably with its target antigens $[12,17]$. Nowadays mouse monoclonal antibody $(\mathrm{mAb})$ are being used for targeting drugs, proteins and peptides to the brain as they are able to recognize a specific antigen $[18,19]$. In this work, the antibody used was the DE2B4 that is able to recognize the $A \beta(1-42)$, once this anti-beta amyloid antibody bind at the region of 1-17 amino acid. The specificity of this $\mathrm{mAb}$ was previously studied [20-22].

Self-assembled monolayers (SAMs) have been used for years in electroanalytical chemistry as the basis for sensors, as they are a simple technique to modify and control the interface of certain materials allowing the immobilization of biomolecules, as for example, antibodies [23,24]. However, the available surface area for the binding of antibody with retention of their bioactivity is still a major issue [17]. For overcoming this problem, SAMs can be coupled with nanoscale materials, which present unique physical properties, ideal for the development of a sensing platform $[17,25]$. Gold nanoparticles (AuNPs) are chemically stable, nontoxic and easy to functionalize [26,27]. From an electroanalytical point of view, AuNPs are particularly interesting because of their high stability, good biological compatibility, excellent conducting capability and high surface-to-volume ratio [26,28,29]. Moreover, the use of AuNPs should not only enable the immobilization of a higher amount of antibody but also preserve the activity of the immobilized biomolecules, thus offering higher sensitivity and selectivity than conventional strategies. These features provide excellent prospects for interfacing biological recognition events with electronic signal transduction and make AuNPs extremely suitable for developing novel and improved electrochemical sensing and biosensing systems [29-31].

In this work, we present a simple and sensitive gold label free immunosensor for the quantification of $\mathrm{AD}$ main biomarker, $A \beta(1-42)$, with the goal of performing a clinical diagnosis and monitor biochemical effects of AD treatments. The sensor's platform was composed of AuNPs which were electrodeposited on the previously mercaptopropionic acid (MPA) modified gold electrode (MPA/Au electrode). Then, the antibody mAb DE2B4 against $A \beta(1-42)$ was functionalized through chemical modification (thiolation) to promote the antibody immobilization on the AuNPs surface with proper orientation which enabled the direct detection of $A \beta(1-42)$. Square-wave voltammetry (SWV) and electrochemical impedance spectroscopy (EIS) were used to characterize the construction of the biosensor and assess the immune reaction between the modified electrode and $A \beta(1-42)$.

\section{Material and methods}

\subsection{Materials}

Mouse monoclonal antibody DE2B4 (1 $\left.\mathrm{mg} \mathrm{mL}^{-1}\right) \operatorname{IgG}(\mathrm{ab} 11132)$ was purchased from Abcam (UK). Human antigen $\beta$-amyloid peptide (1-42), purity $>95 \%$, was purchased from Genscript (USA). Goat anti-mouse IgG secondary antibody was purchased from Pierce antibodies/Thermo Scientific (USA). Sulfuric acid $\left(\mathrm{H}_{2} \mathrm{SO}_{4}\right.$, $98 \%$ ), hydrogen peroxide $\left(\mathrm{H}_{2} \mathrm{O}_{2}, 30 \%\right)$, N-hydroxysuccinimide
(NHS), citric acid, sodium citrate dihydrate, gold(III) chloride solution, ethylenediaminetetraacetic acid (EDTA), 2-imninothiolane hydrochloride, citrate buffer solution, albumin form bovine serum (BSA) N-(3, Dimethylaminopropyl)-N-ethyl-carbodiimide hydrochloride (EDC), 2,2'-Azino-bis(3-ethylbenzothiazoline6-sulfonic acid) diammonium salt (ABTS), cystamine and potassium ferrocyanide $\left(\mathrm{K}_{4}\left[\mathrm{Fe}(\mathrm{CN})_{6}\right] \cdot 3 \mathrm{H}_{2} \mathrm{O}\right)$, potassium ferricyanide $\left(\mathrm{K}_{3} \mathrm{Fe}(\mathrm{CN})_{6}\right)$, potassium hydrogen phosphate $\left(\mathrm{K}_{2} \mathrm{HPO}_{4}\right)$ and potassium dihydrogen phosphate $\left(\mathrm{KH}_{2} \mathrm{PO}_{4}\right)$ were purchased form Sigma-Aldrich (Steinheim, Germany). 2-mercaptoethanol, 3-mercaptopropionic acid solution and glutaraldehyde were purchased from Fluka (Switzerland). Absolute ethanol was obtained from Panreac (Spain). Potassium nitrate $\left(\mathrm{KNO}_{3}\right)$ was purchased from Pronalab (Mexico). Milk powder was obtained from Molico Nestlé. Alumina solution $\left(\gamma-\mathrm{Al}_{2} \mathrm{O}_{3}\right) 0.3 \mu \mathrm{m}$ and $0.05 \mu \mathrm{m}$ were purchased from Gravimeta. Ultrapure water $\left(18.2 \mathrm{M} \Omega \mathrm{cm}^{-1}\right.$ resistivity) was produced by a Milli-Q Simplicity 185 system (Millipore, Molsheim, France).

\subsection{Electrochemical measurements}

Electrochemical experiments were performed with a potentiostat/galvanostat, AUTOLAB model PGSTAT 30 (Metrohm-Eco Chemie, The Netherlands) controlled by a computer through the Model NOVA version 1.9 software. A conventional three-electrode cell was used for all electrochemical measurements: the developed biosensor (based on a polycrystalline gold electrode, BASi MF-2014, surface area $2.0 \mathrm{~mm}^{2}$ and diameter of $1.6 \mathrm{~mm}$ ) as a working electrode, platinum as counter-electrode and a $\mathrm{Ag}|\mathrm{AgCl}| 3 \mathrm{M}$ KClsat reference electrode to which all potentials are referred.

Square-wave voltammetry (SWV) and electrochemical impedance spectroscopy (EIS) were performed using $\mathrm{Fe}(\mathrm{CN})_{6}{ }^{3-/ 4-}$ as electroactive indicator at a concentration of $2.5 \mathrm{mM}$ in $0.1 \mathrm{M}$ PBS solution $(\mathrm{pH}=7.4)$. SWV results were obtained by varying the potential from 0.00 to $0.60 \mathrm{~V}$ at $0.400 \mathrm{~V} / \mathrm{s}$ scan rate. The optimal SWV parameters were a frequency of $100 \mathrm{~Hz}$, amplitude of $40 \mathrm{mV}$ and scan increment of $4 \mathrm{mV}$. EIS measurements were performed using a frequency range from $10^{-1}$ to $10^{5} \mathrm{~Hz}$ with an amplitude perturbation of $5 \mathrm{mV}$.

\subsection{Immunosensor development}

The surface of the bare gold electrode was cleaned using piranha solution ( $30: 70, \mathrm{v} / \mathrm{v}, \mathrm{H}_{2} \mathrm{O}_{2}$ and $\mathrm{H}_{2} \mathrm{SO}_{4}$ ) at room temperature (RT) for $5 \mathrm{~min}$. Then the electrode was polished repeatedly with 0.3 and $0.05 \mu \mathrm{m}$ alumina powder on microfiber cloth. Subsequently the surface was rinsed with ultrapure water and ultrasonically cleaned in absolute ethanol. After that, the electrode was cycled from 0.0 to $1.6 \mathrm{~V}$ in $0.5 \mathrm{M} \mathrm{H}_{2} \mathrm{SO}_{4}$ solution at a scan rate of $100 \mathrm{mV} / \mathrm{s}$. The process was repeated until typical gold cyclic voltammograms were obtained. Finally, the electrode was washed with ultrapure water and modified (Fig. 1).

\subsubsection{Self-assembled monolayer}

Four different SAMs were studied by immersing the gold electrode, for a $12 \mathrm{~h}$ period at RT, in ethanol solutions of cystamine (CYS) (20 mM), cystamine + mercaptoethanol (CYS + ME) $(20 \mathrm{mM})$, mercaptopropionic acid (MPA) (1 mM) and mercaptopropionic acid + mercaptoethanol (MPA + ME) $(1 \mathrm{mM})$. After washing with ultrapure water, the CYS modified electrodes were immersed for a period of $30 \mathrm{~min}$ in a $3 \%$ glutaraldehyde solution, while the other modified (MPA) electrodes were immersed in an EDC/NHS solution.

After selection of the optimum SAM, the incubation time $(2-12 \mathrm{~h}$ ) and concentration of the solution (1-20 mM) for the SAM formation were optimized. 


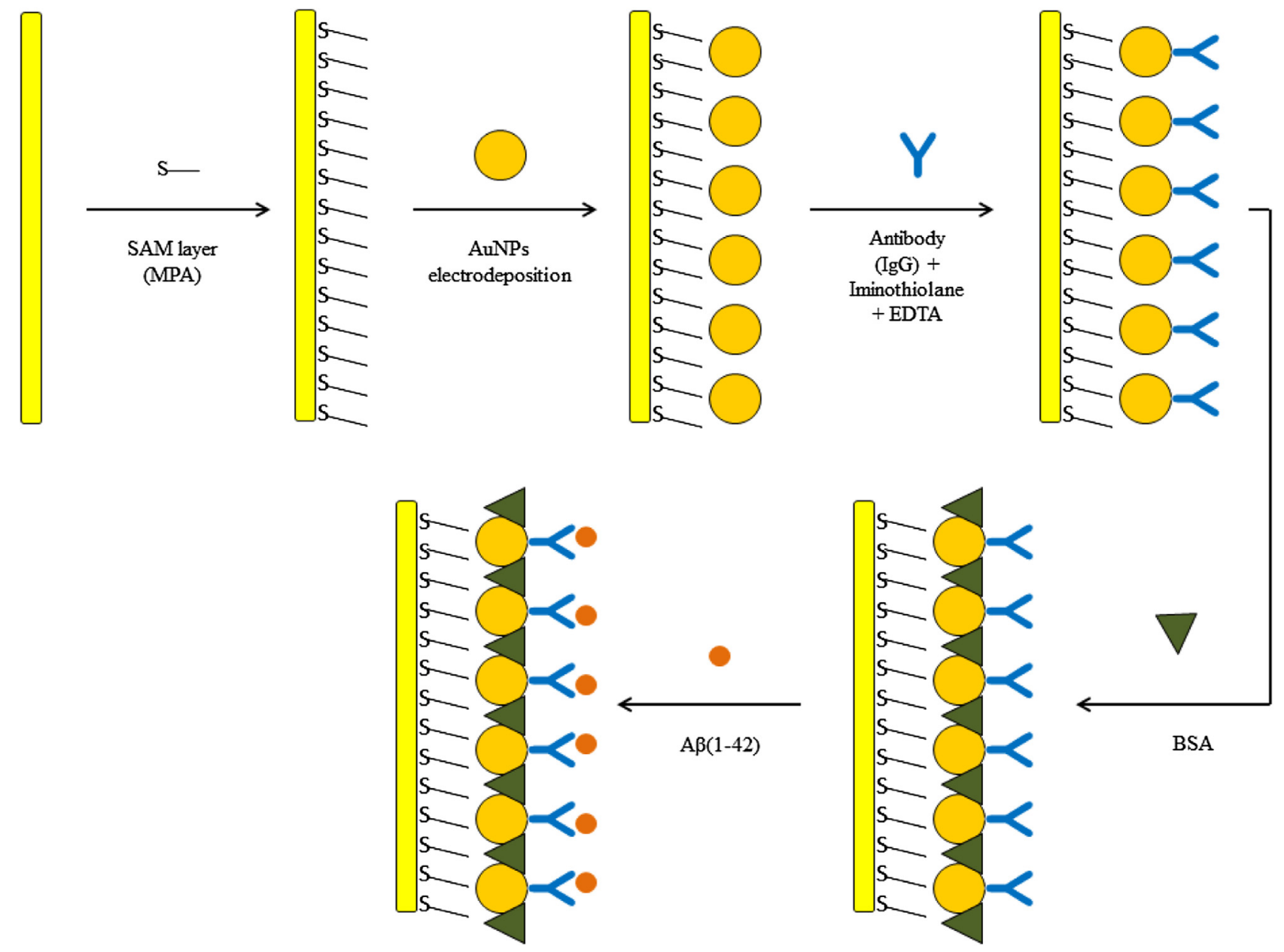

Fig. 1. Schematic illustration of the immunosensor development.

In brief, the final process consisted in immersing the previously cleaned gold electrode for $2 \mathrm{~h}$ at room temperature in an ethanol solution of mercaptopropionic acid ( $5 \mathrm{mM})$. After washing with ultrapure water, a solution of EDC/NHS was dropped on the modified gold electrode surface for $30 \mathrm{~min}$.

\subsubsection{Gold nanoparticles electrodeposition}

To immobilize AuNPs on the electrode surface, the modified (MPA/Au) electrode was immersed in $0.1 \mathrm{M} \mathrm{KNO}_{3}$ solution containing $3 \mathrm{mM} \mathrm{HAuCl}_{4}$ while a $-200 \mathrm{mV}$ working potential was applied to the electrode [32]. In order to optimize AuNPs immobilization, three electrodeposition periods were tested: 100,150 and 200 s.

\subsubsection{Antibody immobilization}

Antibodies against $A \beta(1-42)$ were immobilized on the AuNPs surface using thiol(-SH) groups. The antibodies were prepared through chemical modification (thiolation) with EDTA and Trautís Reagent. A mixed solution containing $1 \mu \mathrm{L}$ of EDTA $(0.28 \mathrm{M}), 82.6 \mu \mathrm{L}$ of iminothiolane $(0.006 \mathrm{mM})$ and monoclonal antibody against $\mathrm{A} \beta(1-42)$ was prepared after dilution with PBS (0.1 M, pH 7.4). The prepared solution reacted for $50 \mathrm{~min}$ at room temperature. After reacting, the solution was completed with PBS in order to make up a volume of $500 \mu \mathrm{L}$. This solution was purified through a sephadex PD MiniTrap G-25 column (GE Healthcare), following the gravity protocol. To immobilize the antibody against $A \beta(1-42)$, the AuNPs/MPA/Au electrode was immersed in the antibody solution $\left(1.0,2.0\right.$ or $\left.5.0 \mu \mathrm{g} \mathrm{mL}^{-1}\right)$ followed by incubation at $4{ }^{\circ} \mathrm{C}$ during five different tested periods $(2,5,7,10$ or $12 \mathrm{~h})$. At last, the anti-
$\mathrm{A} \beta(1-42) /$ AuNPs/MPA/Au electrode was immersed in a $10 \mu \mathrm{g} \mathrm{mL}^{-1}$ BSA solution for $5 \mathrm{~min}$ at $4{ }^{\circ} \mathrm{C}$ in order to block the remaining adsorption-reactive sites (Fig. 1).

\subsection{ELISA}

The functional activity of the antibodies was analyzed by the enzyme-linked immunosorbent assay (ELISA). The surface of 96 well plates (flat-bottom Nunc MaxiSorp ${ }^{\circledR}$ ) was coated with $\mathrm{A} \beta(1-42)$ during $1 \mathrm{~h}$ at $37^{\circ} \mathrm{C}$. After blocking with non fat dry milk $10 \%$, the primary antibody was added to each well. After a washing step, the secondary antibody conjugated with peroxidase (Goat anti-Mouse IgG $(\mathrm{H}+\mathrm{L})$ Cross Adsorbed Secondary Antibody, HRP conjugate, Thermo Scientific-Pierce Antibodies) was allowed to react for $45 \mathrm{~min}$ at $\mathrm{RT}$. To reveal the presence of the antibodies in the wells, a citrate solution was used with citric acid, ABTS (2,2'-azinobis(3-ethylbenzothiazoline-6-sulfonic acid) diammonium salt) and $\mathrm{H}_{2} \mathrm{O}_{2}$. The intensity of the color was measured by spectrophotometry using a Biotek Synergy 2 spectrometer. Wells without primary antibody were used as control.

\subsection{Electrochemical detection of $A \beta(1-42)$}

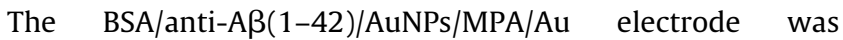
immersed in a PBS solution at $\mathrm{pH} 7.4$ containing a concentration of $A \beta(1-42)$ in the range of $10-1000 \mathrm{pg} \mathrm{mL}^{-1}$ at RT for $10 \mathrm{~min}$. 
All measurements were carried out in triplicate. The current reduction (\% IR):

$\% \mathrm{IR}=\left[1-\left(\mathrm{Ip} / \mathrm{Ip}^{\circ}\right)\right] \times 100$

where $\mathrm{Ip}^{\circ}$ and Ip are the peak currents of $\mathrm{Fe}(\mathrm{CN})_{6}{ }^{3-/ 4-}$ (used as electroactive indicator at a concentration of $2.5 \mathrm{mM}$ in $0.1 \mathrm{M}$ PBS solution, $\mathrm{pH}=7.4$ ) before and after the incubation with $\mathrm{A} \beta(1-42)$, respectively, was employed to obtain $A \beta(1-42)$ analytical curves. Then the electrode was thoroughly rinsed with PBS and ultrapure water to remove unbound antigen, and stored at $4{ }^{\circ} \mathrm{C}$.

\subsection{Scanning electron microscopy}

Scanning electron microscopy (SEM; FEI Quanta 400FEG ESEM/EDAX Genesis X4 M) was used to observe the morphological properties of the developed biosensor.

\section{Results and discussion}

\subsection{Immunosensor development}

\subsubsection{Self-assembled monolayer formation}

The different steps involved in the preparation of the immunosensor are schematically illustrated in Fig. 1. The first optimized step concerned the modification of the gold electrode with

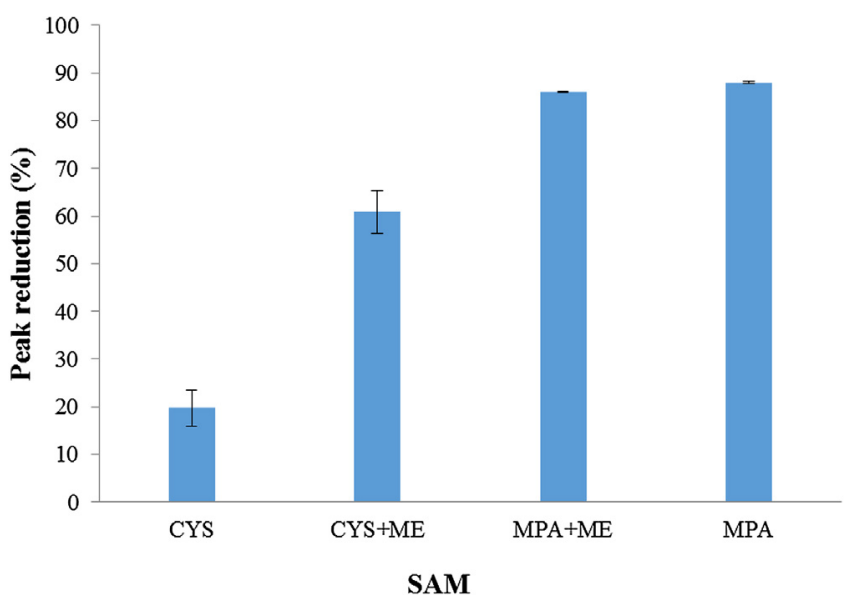

Fig. 2. Influence of the tested self-assembled monolayer (SAM) in the current peak reduction using $\mathrm{Fe}(\mathrm{CN})_{6}{ }^{3-/ 4-}$ as electroactive indicator at a concentration of $2.5 \mathrm{mM}$ in $0.1 \mathrm{M}$ PBS solution ( $\mathrm{pH}=7.4)$. CYS: cystamine $(20 \mathrm{mM})$, CYS + ME: cystamine + mercaptoethanol (20 mM), MPA: mercaptopropionic acid (1 mM), and MPA+ ME: mercaptopropionic acid + mercaptoethanol (1 mM). the several tested SAMs (CYS (20 mM), CYS + ME (20 mM), MPA $(1 \mathrm{mM})$ and MPA + ME (1 mM)). They formed an organic assembly on the electrode surface that led to a block in the electron transfer between the surface of the electrode and the $\mathrm{Fe}(\mathrm{CN})_{6}{ }^{3-/ 4-}$ solution which consequently caused a signal reduction in the peak current. The SAM that best adsorbed to the electrode surface was composed of MPA ( $c a .87 \%$ of peak reduction) and was the selected SAM to form the basis of the developed immunosensor (Fig. 2). Subsequently, the influence of incubation time (2-12 h) and concentration (1-20 mM) was characterized. After the first $2 \mathrm{~h}$ of incubation, only a $1 \%$ reduction in the peak current was observed every $2 \mathrm{~h}$, thus it was concluded that a period of $2 \mathrm{~h}$ is sufficient to form a stable, organized and packed layer on the gold electrode surface. Regarding the concentration, the peak current decreased with increasing of MPA concentrations till ca. $5 \mathrm{mM}$ and higher values led to a stabilization of the peak current, which implied that the electrode surface has been entirely covered with MPA. Thus, $5 \mathrm{mM}$ was considered the most favorable concentration of MPA. The optimized conditions are in accordance with the values found in literature as periods of incubation ranging from $30 \mathrm{~min}-12 \mathrm{~h}$ and MPA concentrations ranging from $0.1-10 \mathrm{mM}$ were found [12,33-38].

\subsubsection{Gold nanoparticles electrodeposition}

The deposition of AuNPs on the modified gold electrode (MPA/Au electrode) reduced the charge transfer resistance and, consequently, a large increase in the peak current was observed. In order to optimize the deposition of AuNPs on the modified electrode surface, three different periods (100, 150 and $200 \mathrm{~s})$ were investigated based on the electroactive indicator peak current using square-wave voltammetry; no significant difference between them was detected since it was possible to recover about $97 \%$ of the original gold signal (before SAM immobilization) in the three cases. Therefore, a period of $100 \mathrm{~s}$ was chosen for the subsequent assays; this electrodeposition period is about three times less than the one presented by Park et al. ([32]). The successful deposition of the AuNPs on MPA/Au electrode was confirmed by SEM (Fig. 3) that showed a rough surface and AuNPs uniformly and densely distributed. These are both indicators of the strong interaction between the AuNPs and the MPA layer.

\subsubsection{Antibody immobilization}

The antibodies were functionalized through chemical modification (thiolation). The aim of this treatment was to immobilize the antibodies on the AuNPs surface with the proper orientation, by using thiol groups, in order to make the antigen binding site available. For this purpose the antibody was treated with Traut's reagent and EDTA. The reagent reacted with the amine groups in the
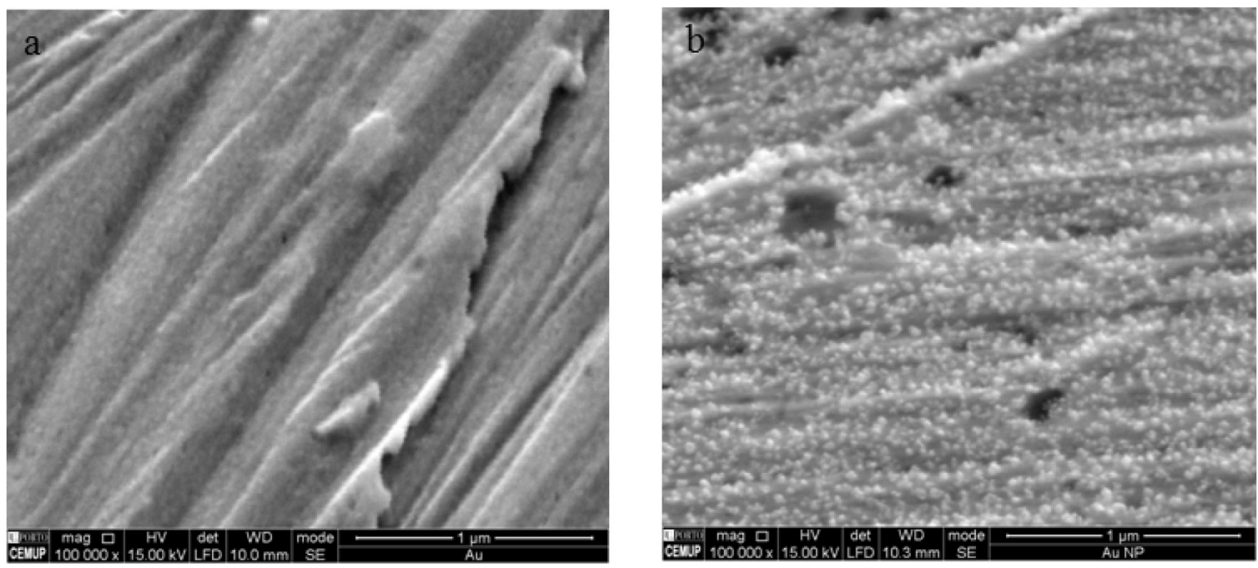

Fig. 3. SEM images of (a) bare gold electrode and (b) AuNPs/MPA/Au electrode. 


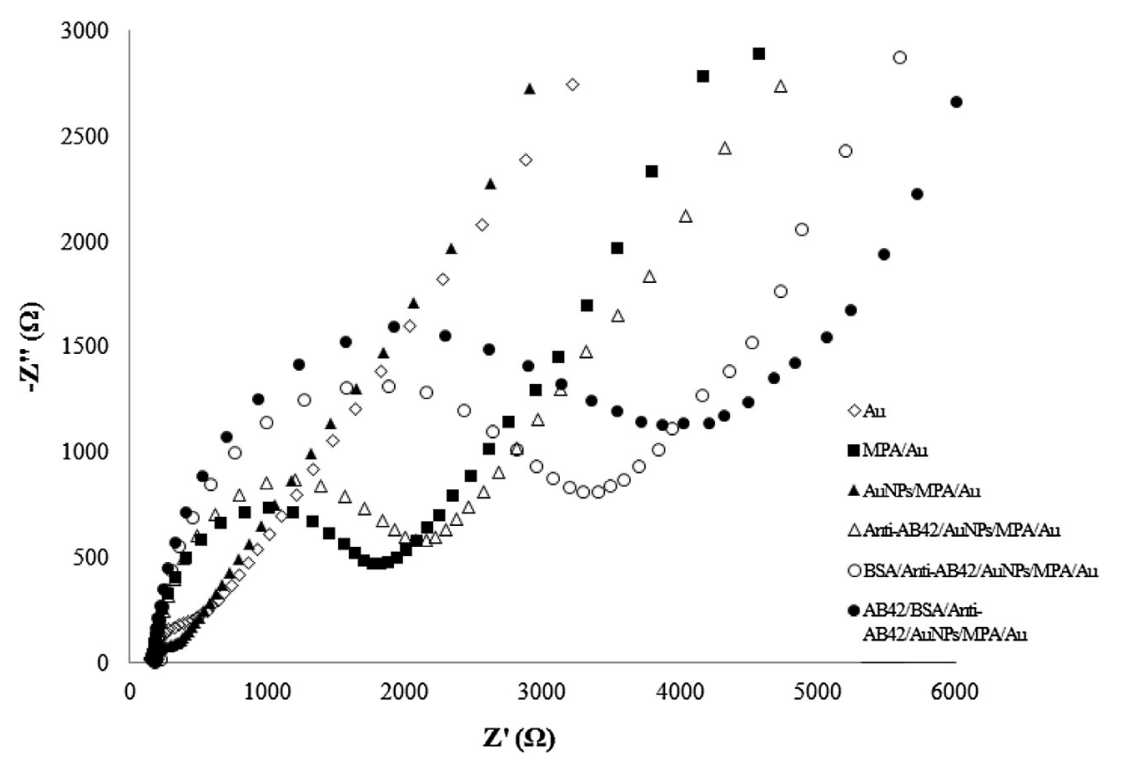

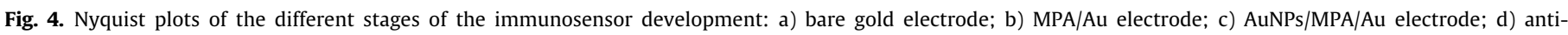

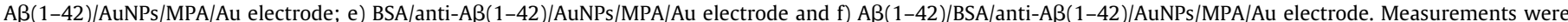
performed in $2.5 \mathrm{mM} \mathrm{Fe}(\mathrm{CN})_{6}{ }^{3-/ 4-}$ solution in $0.1 \mathrm{M} \mathrm{PBS}(\mathrm{pH}=7.4)$ applying a frequency range from $10^{-1}$ to $10^{5} \mathrm{~Hz}$ with an amplitude perturbation of $5 \mathrm{mV}$.

antibodies to result in permanent modifications containing terminal sulfhydryl residues [39]. EDTA was required to stop completely metal-catalyzed oxidation of sulfhydryl groups [39]. To immobilize the antibody against $\mathrm{A} \beta(1-42)$ on the AuNPs/MPA/Au electrode, several concentrations of antibody solution $\left(1.0,2.0\right.$ or $\left.5.0 \mu \mathrm{g} \mathrm{mL}^{-1}\right)$ and incubation times $(2-12 \mathrm{~h}$ ) were tested. The antibody immobilization caused a large signal reduction of the $\mathrm{Fe}(\mathrm{CN})_{6}{ }^{3-/ 4-}$ redox couple due to the formation of a protein layer that partially blocked the AuNPs/MPA/Au electrode surface, making the electron transfer process between the electrode and the solution slower and more difficult. The signal reduction was proportional to the increase of anti-A $\beta(1-42)$ concentration and incubation time. The optimum conditions were found to be a $2.0 \mu \mathrm{g} \mathrm{mL}^{-1}$ antibody concentration and an incubation time of $2 \mathrm{~h}$.

\subsubsection{Electrochemical characterization of the immunosensor}

In order to characterize the fabrication process of the immunosensor, EIS and SWV were recorded at each step and are presented in Figs. 4 and 5, respectively. EIS is one of the most powerful electroanalytical techniques frequently used in characterizing materials and surface interfaces $[17,32,40]$. The advantage of EIS over other electrochemical techniques is that it requires only a small amplitude perturbation from the steady state, which makes it possible to analyze responses theoretically by linearized or otherwise simplified current-potential characteristics [40]. The impedance spectra include a semicircle portion and linear portion, which can be used to describe the interface properties of the electrode for each immobilized step. The semicircle diameter at higher frequencies corresponds to the electron-transfer resistance, which controls the electron transfer kinetics of the redox process at the electrode interface. At lower frequencies, the linear part is typical of a mass diffusion-limited electron-transfer process $[41,42]$. A significant change in the impedance spectra can be observed after each modification of the gold electrode with MPA, AuNPs, anti-A $\beta(1-42), B S A$ and $A \beta(1-42)$ in comparison with the bare gold electrode which exhibited a typical pattern of mass diffusion limited process (Fig. 4). The SAM of MPA formed an organized and packed layer that blocked the surface of the gold electrode increasing the charge-transfer resistance and consequently a semicircle in the impedance spectra was observed. Then AuNPs were electrodeposited onto the MPA/Au electrode and the electron trans- fer resistance significantly decreased, reducing significantly the diameter of the semicircle. AuNPs present high conductivity that improves the electron transfer rate. In contrast after the immobilization of anti-A $\beta(1-42)$ and BSA, the diameters of the semicircle were significantly enlarged due to the generation of an insulating protein layer on the modified electrode surface which hindered the electron transfer. These results also proved that the anti-A $\beta(1-42)$ and BSA were successfully immobilized on the modified electrode surface. AuNPs are widely used nanomaterials because of their large specific surface area, strong adsorption ability, and high conductivity. They can strongly interact with biomaterials and they have been used as a mediator to immobilize biomolecules and to efficiently retain their activity $[26,28,29]$. This pattern of variation is consistent with the results attained by SWV (Fig. 5).

\subsection{Electroanalytical performance of the immunosensor}

The ability of the antibodies of recognizing their ligands was assessed by ELISA. Firstly, the antigen $A \beta(1-42)$ was adsorbed to the bottom surface of a 96 well plate and then it was incubated with the mAb DE2B4 (or with buffer for control); finally, to assess the formation of the antigen-antibody binding, a secondary antibody was used revealing the presence or absence of $A \beta(1-42)$. As a result of this test, it was concluded that a $5 \mathrm{~min}$ period was enough to promote the link between the antigen and the antibody. Still, in order to ensure that maximum sensitivity for detection of $A \beta(1-42)$ was attained, $10 \mathrm{~min}$ of incubation was subsequently applied. For this incubation time in the wells previously coated with amyloid beta, the control (buffer) used in the assays exhibited significantly lower absorbance at $405 \mathrm{~nm}(0.078 \pm 0.003)$ when compared to the antibody $(0.23 \pm 0.03)$, suggesting a sufficient antibody-antigen reaction time.

Under the optimal conditions, the peak current reduction (\%) observed when the biosensor was exposed to different concentrations of $\mathrm{A} \beta(1-42)\left(10-1000 \mathrm{pg} \mathrm{mL}^{-1}\right)$ was recorded. Representative voltammograms are exhibited in Fig. 6a. In the presence of $A \beta(1-42)$, the peak potential shifted positively due to alteration of the interface properties of the biosensor surface (that affected the electron transport) promoted by the capture of $A \beta(1-42)$ by the mouse monoclonal antibody (anti$\mathrm{A} \beta(1-42))$. The analytical curve (Fig. $6 \mathrm{~b}), \mathrm{i}(\%)=14.60\left(\% \frac{\mathrm{mL}}{\mathrm{pg}}\right) \times$ 


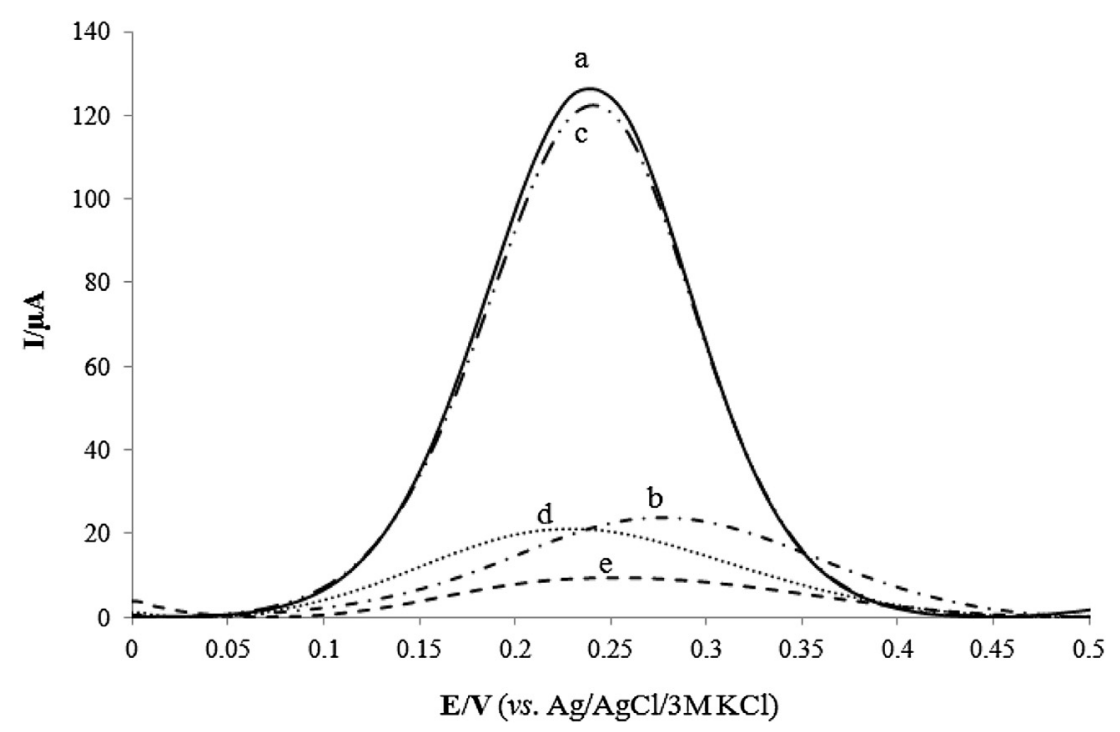

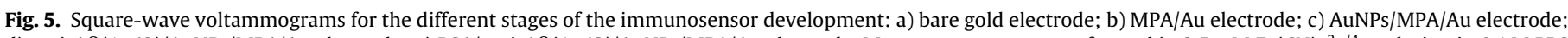

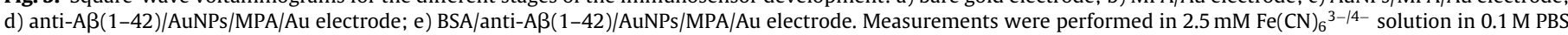
$(\mathrm{pH}=7.4)$
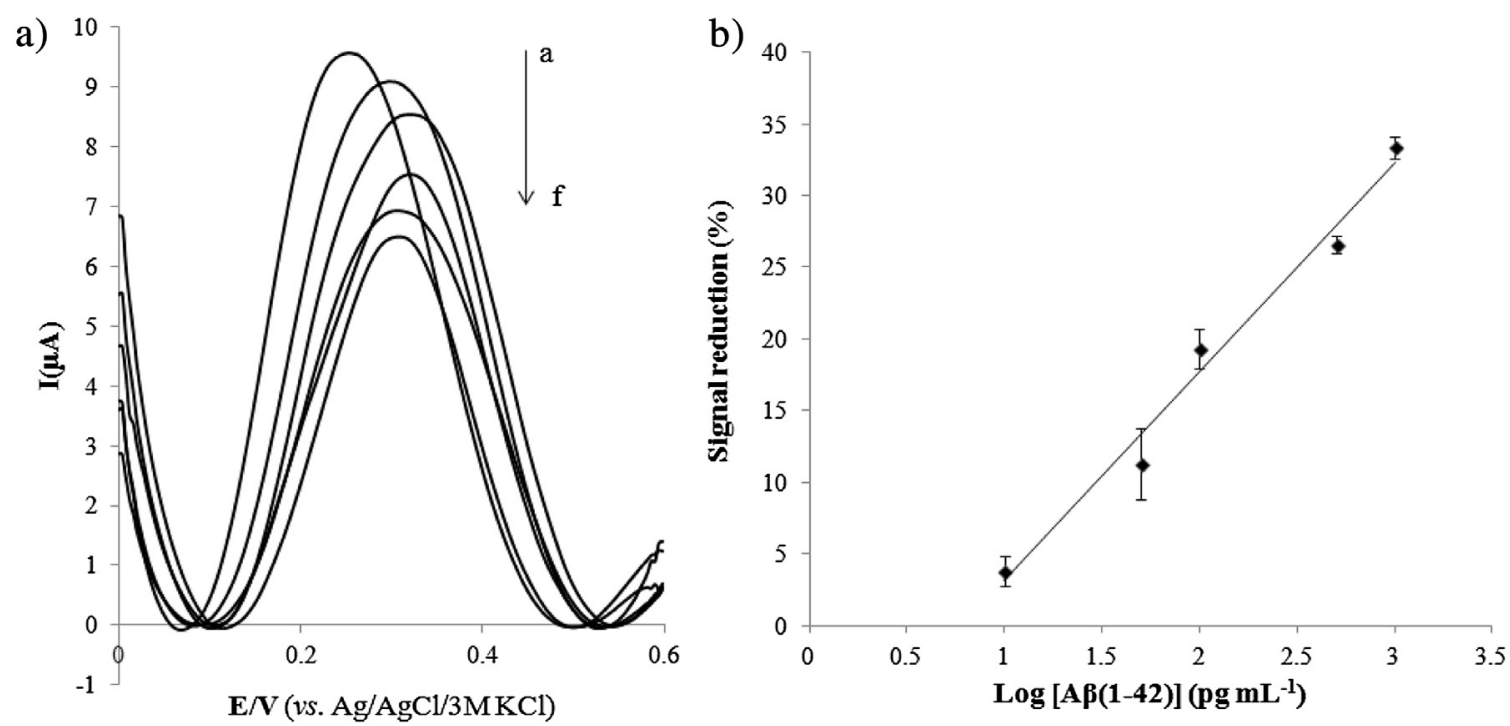

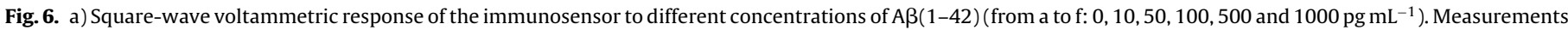
were performed in $2.5 \mathrm{mM} \mathrm{Fe}(\mathrm{CN})_{6}{ }^{3-/ 4-}$ solution in $0.1 \mathrm{M} \mathrm{PBS}(\mathrm{pH}=7.4)$; b) Calibration curve based on the current reduction observed.

$\log$ Diff $6\left[\mathrm{~A} \beta(1-42) \mathrm{pgmL}^{-1}\right]-11.50(\%)$, presented good sensitivity (14.6\% reduction $\mathrm{mL} \mathrm{pg}^{-1}$ ), wide linearity and good distribution of the data, even at low levels, with a correlation coefficient ( $r$ ) of 0.982 . The detection (LOD) and quantification (LOQ) limits were calculated, using the standard deviation of the intercepts and the average of slopes of the straight lines from the analytical curves, to be $5.2 \mathrm{pg} \mathrm{mL}^{-1}\left(1.1 \mathrm{pmol} \mathrm{L}^{-1}\right)$ and $17.4 \mathrm{pg} \mathrm{mL}^{-1}\left(3.85 \mathrm{pmol} \mathrm{L}^{-1}\right)$, respectively. The attained LOD, combined with the simplicity of the proposed immunosensor and fast response, compares favorably with the previously reported ones for the detection of $A \beta(1-42)$ (Table 1) [10,43-54]. Out the fourteen sensors for $A \beta$ (1-42) detection presented in Table 1, only three [47-49] have a LOD in the same range as the one reached in this work but involving longer and much more complex schemes. The detection of $A \beta(1-42)$ is performed in just $10 \mathrm{~min}$ which is significantly lower than the reported periods ( $\geq 30 \mathrm{~min}$ [55]). Moreover, due to its simplicity and short analysis time this method allows real time monitoring and with its label-free detection it obviates the need of expensive biotin or enzyme-linked antibody and functionalized nanoparticles for recognition and signal amplification, reducing the operation complexity and assay cost.

Additionally, the intra-repeatability was estimated at a controlled $A \beta(1-42)$ concentration of $0.30 \mathrm{ng} \mathrm{mL}^{-1}$. Intra-day $(n=6)$ exhibited relative standard deviations (RSD) of 4.0. The reproducibility of immunosensor was also assessed using three different modified electrodes and the attained RSD was $2.4 \%$. The long-time stability of the immunosensor was evaluated. The current response of the prepared immunosensor decreased $18 \%$ after five days storage in PBS $(\mathrm{pH}=7.4)$ at $4{ }^{\circ} \mathrm{C}$ thus presenting acceptable stability. Overall, the proposed procedures exhibit appropriate features for analytical purposes.

The accuracy and applicability of the proposed biosensor was tested by recovery assays performed at two spiking levels. 
Table 1

Review of reported immunosensors for $A \beta(1-42)$ detection.

\begin{tabular}{|c|c|c|c|c|c|}
\hline Transducer & Immobilization & Analyte & Detection & $\mathrm{LOD}\left(\mathrm{pg} \mathrm{mL}^{-1}\right)$ & Ref. \\
\hline Silicon/Silicon oxide & Poly(DMA-co-NAS-co-MAPS) ${ }^{*}$ & $A \beta(1-42)$ & Circular dichroism spectroscopy & 73 & {$[10]$} \\
\hline Silicon wafer & $\begin{array}{l}\text { Functionalization of the substrate } \\
\text { with carboxylated } \\
\text { alkyltrichlorosilane }\end{array}$ & $A \beta(1-42)$ & $\begin{array}{l}\text { X-ray Photoemissive Spectroscopy } \\
\text { and Fluorescent microscopy }\end{array}$ & $3.0 \times 10^{5}$ & [43] \\
\hline Carbon electrode & $\begin{array}{l}\text { AuNPs/SAM formation of the } \\
\text { acetylenyl group/cycloaddition } \\
\text { reaction of an azide-terminated } \\
\text { sialic acid }\end{array}$ & $A \beta(1-40)$ and $A \beta(1-42)$ & Differential Pulse Voltammetry & $4.5 \times 10^{6 \#}$ & {$[44]$} \\
\hline Gold electrode & $\begin{array}{l}\text { Peptide probe } \\
\text { (11-mercaptoundecanoic } \\
\text { acid + Peptide chain + Ferrocene)/9- } \\
\text { mercapto-1-nonanol }\end{array}$ & $\mathrm{A} \beta(1-42)$ soluble oligomer & Square-Wave Voltammetry & $1.1 \times 10^{3 \#}$ & [45] \\
\hline $\begin{array}{l}\text { Glassy carbon } \\
\text { electrode }\end{array}$ & $\begin{array}{l}\text { Direct immobilization on the } \\
\text { electrode surface }\end{array}$ & $A \beta(1-40)$ and $A \beta(1-42)$ & Square-Wave Voltammetry & $7.0 \times 10^{5}$ & {$[46]$} \\
\hline $\begin{array}{l}\text { CNT film-based } \\
\text { biosensor with a metal } \\
\text { semiconductor field } \\
\text { effect transistor } \\
\text { structure }\end{array}$ & $\begin{array}{l}\text { Au with protein } G \text { or auto } \\
\text { displayed Z-domains of protein-A }\end{array}$ & $A \beta(1-42)$ & Study of conductance & 1 & [47] \\
\hline $\begin{array}{l}\text { Gold screen printed } \\
\text { electrode }\end{array}$ & $\begin{array}{l}\text { POPA co-polymer }{ }^{* *} / \text { Biotinylated } \\
\text { cellular prion protein } \\
\text { (PrPc-residues95-110) }\end{array}$ & $A \beta(1-42)$ oligomers & $\begin{array}{l}\text { Electrochemical Impedance } \\
\text { Spectroscopy }\end{array}$ & $2.3^{\# \#}$ & {$[48]$} \\
\hline $\begin{array}{l}\text { Anodic aluminium } \\
\text { oxide substrate (AAO) }\end{array}$ & $\begin{array}{l}\text { Thin gold film sputtered onto the } \\
\text { AAO/AuNPs/11- } \\
\text { mercaptoundecanoic acid } \\
\text { SAM }\end{array}$ & $A \beta(1-42)$ & $\begin{array}{l}\text { Electrochemical Impedance } \\
\text { Spectroscopy }\end{array}$ & 1 & [49] \\
\hline $\begin{array}{l}\text { Glassy carbon } \\
\text { electrode }\end{array}$ & $\begin{array}{l}\text { Bio-conjugate of horseradish } \\
\text { peroxidase(HRP)-AuNPs-gelsolin }\end{array}$ & $\begin{array}{l}\text { Soluble } \\
A \beta(1-40) / A \beta(1-42)\end{array}$ & Differential Pulse Voltammetry & $126^{\# \#}$ & {$[50]$} \\
\hline Gold electrode & $\begin{array}{l}\text { Alkalinephospahte-cystein- } \\
\text { Prp(95-115)peptide }\end{array}$ & $\mathrm{A} \beta$ oligomers & Cyclic voltammetry & $13.5^{\#}$ & {$[51]$} \\
\hline $\begin{array}{l}\text { Screen-printed carbon } \\
\text { electrodes }\end{array}$ & $\begin{array}{l}\text { AuNPs/Streptavidin/Biotin-A } \beta \\
(1-42)\end{array}$ & $A \beta(1-42)$ & Cyclic voltammetry & 100 & {$[52]$} \\
\hline Gold electrode & $\begin{array}{l}\text { mercaptopropionic acid } \\
\text { SAM/Antibody/Streptavidin- } \\
\text { conjugated alkaline phosphatase } \\
\text { and biotinylated } A \beta \text { peptides }\end{array}$ & $A \beta(1-42)$ and total $A \beta$ & Amperometric detection & $22.6^{\# \#}$ & [53] \\
\hline $\begin{array}{l}\text { Carbon disposable } \\
\text { electrochemical } \\
\text { printed chip }\end{array}$ & SAM-AuNPs & $A \beta(1-42)$ & $\begin{array}{l}\text { Electrochemical impedance } \\
\text { spectroscopy }\end{array}$ & $2.6 \times 10^{3 \# \#}$ & [54] \\
\hline Gold electrode & $\begin{array}{l}\text { MPA SAM/AuNPs/Anti- A } \beta(1-42)- \\
\text { (EDTA+ Traut's reagent) }\end{array}$ & $A \beta(1-42)$ & Square-Wave Voltammetry & 5.2 & This work \\
\hline
\end{tabular}

*Ter-copolymer made from dimethylacrylamide (DMA),3-(trimethoxysilyl)propylmethacrylate(MAPS) and N-Acryloyloxysuccinimide(NAS).

${ }^{* *}$ Co-polymer of polytyr- amine/3-(4-hydroxyphenyl) propionic acid.

\#Value was expressed in $\mu \mathrm{mol} \mathrm{L}^{-1}$ and converted to $\mathrm{pg} \mathrm{mL}^{-1}$.

\#\#Value was expressed in $\mathrm{pM}$ and converted to $\mathrm{pg} \mathrm{mL}$.

Table 2

Recovery assays $(n=4)$ of the proposed immunosensor.

\begin{tabular}{lllll}
\hline Sample & $\begin{array}{l}\text { Standard value } \\
\left(\mathrm{pg} \mathrm{mL}^{-1}\right)\end{array}$ & Found $\left(\mathrm{pg} \mathrm{mL}^{-1}\right)$ & Recovery $(\%)$ & $\begin{array}{l}\text { Relative standard } \\
\text { deviation }(\%)\end{array}$ \\
\hline 1 & 30 & 27.1 & 90.3 & 24.7 \\
2 & 300 & 280.9 & 93.6 & 3.5 \\
\hline
\end{tabular}

Recoveries of $90.3 \%$ and $93.6 \%$ were reached at the fortification concentration of 30 and $300 \mathrm{pg} \mathrm{mL}^{-1}$, respectively (Table 2), demonstrating the good accuracy and precision of the developed immunosensor. Still, a relatively high standard deviation $(24.7 \%)$ was obtained at the lowest spiking level which may be explained by the increase of variability observed during analytical measurements (independently of the applied technique) when levels near the LOQ are quantified. Thus, the label-free methodology presented in this work proves to be simpler, faster and cheaper than other electrochemical biosensors while maintaining appropriate electroanalytical performance. However, it can be expected that the selected mouse monoclonal antibody may be also able to recognize $A \beta(1-40)$. Nowadays, substantial evidence indicates that the quantity of $A \beta$ in different pools, may be more closely related to disease state. Due to this new relevant discover, it is also important to determine the total amount of $A \beta$ (between 38 and 43 amino acids). Still, $A \beta(1-42)$ is the main biomarker of Alzheimer's disease and the more cytotoxic [3]. This peptide is the major component of the senile plaques found in Alzheimer's disease; $A \beta(1-42)$ is the most fibrillogenic sequence and is thus associated with disease states. An $A \beta(1-42)$ concentration of $<500 \mathrm{pg} \mathrm{mL}^{-1}(0.1 \mathrm{nM})$ in cerebral spinal fluid is indicative that $A \beta(1-42)$ is accumulating in the brain [10]. Biosensors for $A \beta$ detection are scarce and even scarcer those that tested different $A \beta$ peptides [55,56]. In that regards, it is worth to mention the work that has been performed by Liu et al. [53,56]. This research team developed two sensitive and selective electrochemical immunosensors for determining the total concentration of $A \beta(1-40 / 1-42)$ and the relative level of $A \beta(1-42)$ by signal amplification of $A \beta(1-16)$-heme-modified gold nanoparticles (AuNPs) (A $\beta(1-16)$-heme-AuNPs) and p-aminophenol ( $p$-AP) redox cycling, respectively [53-56].

\section{Conclusions}

A simple and rapid label-free electrochemical immunosensor based on a modified gold electrode for the detection of $A \beta(1-42)$ was developed. The structure of the presented immunosensor exhibits several advantages. The MPA self-assembled monolayer formed a stable, organized and packed layer on the surface of 
the gold electrode which enabled a fast and successful electrodeposition of AuNPs. Due to their excellent conductive and catalytic properties, AuNPs acted as an "electronic wire" and promoted the communication between the mediator and the electrode surface, and amplified the electrochemical reactions. The proposed immunosensor showed a low detection limit, wide linear range, good accuracy and reproducibility. Furthermore, the proposed biosensor offers interesting possibilities for detection of the selected biomarker since it uses simple and relatively inexpensive instrumentation. Its application is intended to be cheaper, easier and faster than conventional methodologies. It can constitute a novel approach to monitor biochemical effects of AD treatments, and to facilitate the clinical diagnostic because biomarker levels are significantly related with stage of AD. However, it can be expected that the selected mouse monoclonal antibody may be also able to recognize $A \beta(1-40)$ which may be a limitation of this study. Since data attained with real biological samples (plasma and cerebral spinal fluid) are precious, more comprehensive studies will be conducted in the near future.

\section{Acknowledgments}

This work was supported by European Union (FEDER funds through COMPETE) and National Funds (Fundação para a Ciência e Tecnologia) through projects UID/QUI/50006/2013POCI/01/0145/FEDER/007265 and UID/EQU/00511/2013-LEPABE, by the FCT/MEC with national funds and co-funded by FEDER in the scope of the P2020 Partnership Agreement. Additional financial support was provided by Fundação para Ciência e Tecnologia through project PTDC/QUI-BIQ/102827/2008.

\section{References}

[1] K. Blennow, M.J. de Leon, H Zetterberg, Alzheimer's disease, Lancet, 368 387-403.

[2] J.L. Cummings, G. Cole, Alzheimer disease, JAMA: J. Am. Med. Assoc. 287 (2002) 2335-2338.

[3] J.L. Cummings, Biomarkers in Alzheimer's disease drug development, Alzheimer's Dementia: J. Alzheimer's Assoc. 7 (2011) e13-44.

[4] D.Y. Kang, J.H. Lee, B.K. Oh, J.W. Choi, Ultra-sensitive immunosensor for beta-amyloid (1-42) using scanning tunneling microscopy-based electrical detection, Biosens. Bioelectron. 24 (2009) 1431-1436.

[5] H. Hampel, Y. Shen, D.M. Walsh, P. Aisen, L.M. Shaw, H. Zetterberg, et al., Biological markers of amyloid beta-related mechanisms in Alzheimer's disease, Exp. Neurol. 223 (2010) 334-346.

[6] R. Craig-Schapiro, A.M. Fagan, D.M. Holtzman, Biomarkers of alzheimer's disease, Neurobiol. Dis. 35 (2009) 128-140.

[7] J. Hardy, D.J. Selkoe, The amyloid hypothesis of Alzheimer's disease: progress and problems on the road to therapeutics, Science (New York NY) 297 (2002) 353-356.

[8] H. Zetterberg, K. Blennow, E. Hanse, Amyloid $\beta$ and APP as biomarkers for Alzheimer's disease, Exp. Gerontol. 45 (2010) 23-29.

[9] N. Andreasen, K. Blennow, Beta-amyloid (Abeta) protein in cerebrospinal fluid as a biomarker for Alzheimer's disease, Peptides 23 (2002) 1205-1214.

[10] P. Gagni, L. Sola, M. Cretich, M. Chiari, Development of a high-sensitivity immunoassay for amyloid-beta 1-42 using a silicon microarray platform, Biosens. Bioelectron. 47 (2013) 490-495.

[11] V.C. Cullen, R.A. Fredenburg, C. Evans, P.R. Conliffe, M.E. Solomon, Development and advanced validation of an optimized method for the quantitation of Abeta42 in human cerebrospinal fluid, AAPS J. 14 (2012) 510-518.

[12] X. Liu, W.-J. Li, L. Li, Y. Yang, L.-G. Mao, Z. Peng, A label-free electrochemical immunosensor based on gold nanoparticles for direct detection of atrazine, Sens. Actuators B 191 (2014) 408-414.

[13] A.E. Peh, S.F. Li, Dengue virus detection using impedance measured across nanoporous alumina membrane, Biosens. Bioelectron. 42 (2013) 391-396.

[14] S. Yu, Q. Wei, B. Du, D. Wu, H. Li, L. Yan, et al., Label-free immunosensor for the detection of kanamycin using $\mathrm{Ag} @ \mathrm{Fe} 3 \mathrm{O} 4$ nanoparticles and thionine mixed graphene sheet, Biosens. Bioelectron. 48 (2013) 224-229.

[15] Y. Zhang, H. Chen, X. Gao, Z. Chen, X. Lin, A novel immunosensor based on an alternate strategy of electrodeposition and self-assembly, Biosens. Bioelectron. 35 (2012) 277-283.

[16] C.A. Wijayawardhana, H.B. Halsall, W.R. Heineman, Electrochemical Immunoassay Encyclopedia of Electrochemistry, Wiley-VCH Verlag GmbH \& Co. KGaA, 2007.
[17] C.-C. Lin, L.-C. Chen, C.-H. Huang, S.-J. Ding, C.-C. Chang, H.-C. Chang, Development of the multi-functionalized gold nanoparticles with electrochemical-based immunoassay for protein A detection, J. Electroanal. Chem. 619-620 (2008) 39-45.

[18] M.I. Alam, S. Beg, A. Samad, S. Baboota, K. Kohli, J. Ali, et al., Strategy for effective brain drug delivery, Eur. J. Pharma. Sci: Off. J. Eur. Fed. Pharma. Sci. 40 (2010) 385-403.

[19] J.A. Loureiro, B. Gomes, M.A. Coelho, M. do Carmo Pereira, S. Rocha, Targeting nanoparticles across the blood-brain barrier with monoclonal antibodies, Nanomedicine (London England) 9 (2014) 709-722.

[20] J. Ritter, T. Schmitz, L.J. Chew, C. Buhrer, W. Mobius, M. Zonouzi, et al. Neonatal hyperoxia exposure disrupts axon-oligodendrocyte integrity in the subcortical white matter, J. Neurosci: Off. J. Soc. Neurosci. 33 (2013) 8990-9002.

[21] M. Bomba, D. Ciavardelli, E. Silvestri, L.M. Canzoniero, R. Lattanzio, P. Chiappini, et al., Exenatide promotes cognitive enhancement and positive brain metabolic changes in PS1-KI mice but has no effects in 3xTg-AD animals, Cell. Death. Dis. 4 (2013) e612.

[22] C. Corona, V. Frazzini, E. Silvestri, R. Lattanzio, R. La Sorda, M. Piantelli, et al., Effects of dietary supplementation of carnosine on mitochondrial dysfunction, amyloid pathology, and cognitive deficits in 3xTg-AD mice, PLoS One 6 (2011) e17971.

[23] S. Dong, J. Li, Self-assembled monolayers of thiols on gold electrodes for bioelectrochemistry and biosensors, Bioelectrochem. Bioenerg. 42 (1997) 7-13.

[24] C. Vericat, M.E. Vela, G. Benitez, P. Carro, R.C. Salvarezza, Self-assembled monolayers of thiols and dithiols on gold: new challenges for a well-known system, Chem. Soc. Rev. 39 (2010) 1805-1834.

[25] T.L. Doane, C. Burda, The unique role of nanoparticles in nanomedicine: imaging, drug delivery and therapy, Chem. Soc. Rev. 41 (2012) 2885-2911.

[26] F. Lu, T.L. Doane, J.-J. Zhu, C. Burda, Gold nanoparticles for diagnostic sensing and therapy, Inorg. Chim. Acta 393 (2012) 142-153.

[27] D.A. Giljohann, D.S. Seferos, W.L. Daniel, M.D. Massich, P.C. Patel, C.A. Mirkin, Gold nanoparticles for biology and medicine, Angew. Chem. Int. Ed. 49 (2010) 3280-3294.

[28] S. Guo, E. Wang, Synthesis and electrochemical applications of gold nanoparticles, Anal. Chim. Acta 598 (2007) 181-192.

[29] G.K. Ahirwal, C.K. Mitra, Gold nanoparticles based sandwich electrochemical immunosensor, Biosens. Bioelectron. 25 (2010) 2016-2020.

[30] M.C. Daniel, D. Astruc, Gold nanoparticles: assembly, supramolecular chemistry, quantum-size-related properties, and applications toward biology catalysis, and nanotechnology, Chem. Rev. 104 (2004) 293-346.

[31] K. Omidfar, F. Khorsand, M. Darziani Azizi, New analytical applications of gold nanoparticles as label in antibody based sensors, Biosens. Bioelectron. 43 (2013) 336-347.

[32] B.-W. Park, D.-Y. Yoon, D.-S. Kim, Formation and modification of a binary self-assembled monolayer on a nano-structured gold electrode and its structural characterization by electrochemical impedance spectroscopy, J. Electroanal. Chem. 661 (2011) 329-335.

[33] M.J.S. Bhuvana, V. Narayanan, W. Dharuman, J.H. Teng, K. Hahn Jayakumar, Gold surface supported spherical liposome-gold nano-particle nano-composite for label free DNA sensing, Biosens. Bioelectron. 41 (2013) 802-808.

[34] J. Liu, Y. Qin, D. Li, T. Wang, Y. Liu, J. Wang, et al., Highly sensitive and selective detection of cancer cell with a label-free electrochemical cytosensor, Biosens. Bioelectron. 41 (2013) 436-441.

[35] S. Chunta, J. Suk-Anake, K. Chansiri, C. Promptmas, A piezoelectric-based immunosensor for high density lipoprotein particle measurement, Analyst 139 (2014) 4586-4592.

[36] Y. Chen, Y. Yang, Y. Tu, An electrochemical impedimetric immunosensor for ultrasensitive determination of ketamine hydrochloride, Sens. Actuators B $183(2013) 150-156$.

[37] X. Liu, H. Wu, Y. Zheng, Z. Wu, J. Jiang, G. Shen, et al., A sensitive electrochemical immunosensor for $\alpha$-fetoprotein detection with colloidal gold-based dentritical enzyme complex amplification, Electroanalysis 22 (2010) 244-250.

[38] D. Li, Y. Feng, L. Zhou, Z. Ye, J. Wang, Y. Ying, et al., Label-free capacitive immunosensor based on quartz crystal Au electrode for rapid and sensitive detection of Escherichia coli O157:H7, Anal. Chim. Acta 687 (2011) 89-96.

[39] G.T. Hermanson, Bioconjugate Techniques, Elsevier Science, 2010

[40] M.M. Billah, C.S. Hodges, H.C. Hays, P.A. Millner, Directed immobilization of reduced antibody fragments onto a novel SAM on gold for myoglobin impedance immunosensing, Bioelectrochemistry (Amsterdam Netherlands) 80 (2010) 49-54.

[41] X.L. Liu, H. Xie Li, Electrochemical biosensor based on reduced graphene oxide and Au nanoparticles entrapped in chitosan/silica sol-gel hybrid membranes for determination of dopamine and uric acid, J. Electroanal. Chem. 682 (2012) $158-163$.

[42] H. Fan, Y. Zhang, D. Wu, H. Ma, X. Li, Y. Li, et al., Construction of label-free electrochemical immunosensor on mesoporous carbon nanospheres for breast cancer susceptibility gene, Anal. Chim. Acta 770 (2013) 62-67.

[43] M. Ammar, C. Smadja, L. Giang Thi Phuong, M. Azzouz, J. Vigneron, A. Etcheberry, et al., A new controlled concept of immune-sensing platform for specific detection of Alzheimer's biomarkers, Biosens. Bioelectron. 40 (2013) 329-335. 
[44] M. Chikae, T. Fukuda, K. Kerman, K. Idegami, Y. Miura, E. Tamiya, Amyloid- $\beta$ detection with saccharide immobilized gold nanoparticle on carbon electrode, Bioelectrochemistry (Amsterdam Netherlands) 74 (2008) 118-123.

[45] H. Li, Y. Cao, X. Wu, Z. Ye, G. Li, Peptide-based electrochemical biosensor for amyloid $\beta$ 1-42 soluble oligomer assay, Talanta 93 (2012) 358-363.

[46] M. Vestergaard, K. Kerman, M. Saito, N. Nagatani, Y. Takamura, E. Tamiya, A rapid label-free electrochemical detection and kinetic study of Alzheimer's amyloid beta aggregation, J. Am. Chem. Soc. 127 (2005) 11892-11893.

[47] J. Oh, G. Yoo, Y.W. Chang, H.J. Kim, J. Jose, E. Kim, et al., A carbon nanotube metal semiconductor field effect transistor-based biosensor for detection of amyloid-beta in human serum, Biosens. Bioelectron. 50 (2013) 345-350.

[48] J.V. Rushworth, A. Ahmed, H.H. Griffiths, N.M. Pollock, N.M. Hooper, P.A. Millner, A label-free electrical impedimetric biosensor for the specific detection of Alzheimer's amyloid-beta oligomers, Biosens. Bioelectron. 56 (2014) 83-90.

[49] C.-C. Wu, B.-C. Ku, C.-H. Ko, C.-C. Chiu, G.-J. Wang, Y.-H. Yang, et al., Electrochemical impedance spectroscopy analysis of A-beta (1-42) peptide using a nanostructured biochip, Electrochim. Acta 134 (2014) 249-257.

[50] Y. Yu, X. Sun, D. Tang, C. Li, L. Zhang, D. Nie, et al., Gelsolin bound $\beta$-amyloid peptides(1-40/1-42): Electrochemical evaluation of levels of soluble peptide associated with Alzheimer's disease, Biosens. Bioelectron. 68 (2015) 115-121.

[51] L Liu N, Xia M, Jiang N, S. Huang, S Li Guo, et al., Electrochemical detection of amyloid- $\beta$ oligomer with the signal amplification of alkaline phosphatase plus electrochemical-chemical-chemical redox cycling, J. Electroanal. Chem. 754 (2015) 40-45.

[52] E.C. Rama, M.B. González-García, A. Costa-García, Competitive electrochemical immunosensor for amyloid-beta 1-42 detection based on gold nanostructurated Screen-Printed Carbon Electrodes, Sens. Actuators B 201 (2014) 567-571.

[53] L. Liu, Q. He, F. Zhao, N. Xia, H. Liu, S. Li, et al., Competitive electrochemical immunoassay for detection of $\beta$-amyloid (1-42) and total $\beta$-amyloid peptides using p-aminophenol redox cycling, Biosens. Bioelectron. 51 (2014) 208-212.

[54] T.T.N. Lien, Y. Takamura, E. Tamiya, MdC Vestergaard, Modified screen printed electrode for development of a highly sensitive label-free impedimetric immunosensor to detect amyloid beta peptides, Anal. Chim. Acta 892 (2015) 69-76.

[55] A. Kaushik, R.D. Jayant, S. Tiwari, A. Vashist, M. Nair, Nano-biosensors to detect beta-amyloid for Alzheimer's disease management, Biosens. Bioelectron. 80 (2016) 273-287.

[56] L. Liu, B. Zhou, Electrochemical methods for detecting $\beta$-amyloid peptides and monitoring their aggregation, Int. J. Electrochem. Sci. 10 (2015) 7684-7695.

\section{Biographies}

Pedro Carneiro obtained his MSc and BSc at the Faculty of Engineering of the University of Porto and at the Faculty of Biotechnology of the Catholic University of Portugal, respectively. He is currently working as a researcher at LEPABE and REQUIMTE-LAQV located in the Department of Chemical Engineering, Faculty of Engineering of the University of Porto and in the Instituto Superior de Engenharia do Porto, respectively. His research interests include immunosensors, nanomaterials and neurodegenerative diseases.

Joana Angélica Loureiro is graduated in Chemical Engineering from Faculty of Engineering, University of Porto (Portugal) in 2010, and received her Ph.D. degree in Chemical and Biological Engineering from the same university in 2013. Currently she is a post-doc researcher at Laboratory for Process Engineering. Environment Biotechnology and Energy (Porto, Portugal). Her scientific research is directed to the nanotechnology and interfacial phenomena applied to the Alzheimer's and Parkinson's diseases.

Cristina Delerue-Matos obtained her PhD in Chemical-Physics, specialty in electrochemistry, in 1990. At the moment, she is coordinator professor at the School of Engineering of the Polytechnic Institute of Porto (ISEP-IPP, Portugal) and also coordinates the REQUIMTE/ISEP research group (www.graq.isep.ipp.pt). Her research interests include the development of analytical methodologies for environmental, food, pharmaceutical, biochemical and industrial control. She is co-author of more than 175 publications in scientific journals.

Simone Morais has a Ph.D. (1998) in Chemical Engineering from the faculty of Engineering of the University of Porto. She is Auxiliary Professor at the Department of Chemical Engineering at the School of Engineering of the Polytechnic of Porto (Portugal) and permanent researcher at REQUIMTE. Her main research interests are electrochemistry, (bio)sensors and environmental sciences. S. Morais co-authored about 90 papers in refereed journals.

Maria C. Pereira received her $\mathrm{PhD}$ in Chemical Engineering from the University of Porto in 1998. She is Assistant Professor at the Department of Chemical Engineering, Faculty of Engineering, University of Porto, Portugal, and develops her research work at LEPABE (Laboratory for Process Engineering, Environment, Biotechnology and Energy). Her research fields cross biophysics, supramolecular interactions including novel nano-engineered biomaterials for therapeutic applications, and environmental sciences/air pollutants. She is the author or co-author of more than 90 papers in refereed journals. 